\title{
Induction of Flowering and Fruiting in Plantlets of Tomato (Lycopersicon esculentum Mill.)
}

\section{Wina Dian Savitri, Florentinus W.N. Nurtyandi, and Popy Hartatie Hardjo}

Department of Biology, Faculty of Technobiology, University of Surabaya

Correspondence: Wina Dian Savitri

Email: winasavitri@staff.ubaya.ac.id

Submitted : 07-09-2018, Revised : 23-10-2018, Accepted : 10-12-2018

\begin{abstract}
Tomato (Lycopersicon esculentum Mill.) is used as vegetable or fruit by people around the world. The effective and efficient propagation of tomato is needed due to the high demand, while its availability is not enough to meet the consumer demand. In vitro flowering and fruiting is useful in order to produce high quality hybrid seeds. Also, this can be produced in all seasons. Beside, this technique is beneficial to improve genetic diversity in tomato. In addition, tomato has natures that make it compatible as a plant model. This experiment intended to find the best combination of plant growth regulators or plant retardants to induce flower and fruit from tomato plantlets. The results will be beneficial to overcome self-fertilization in tomato, as well as to promote higher genetic biodiversity in tomato. To do so, some plant growth regulators (6-Benzylaminopurine (BAP), Indoleacetic acid (IAA), and Gibberellin (GA3)) and retardants (Ancymidol and Paclobutrazol) were used to find the best combination in inducing in vitro flowering and fruiting. The results showed that $1 \mathrm{mg} \cdot L^{-1} B A P$ was the best candidate plant growth regulator to produce the in vitro flowers and fruits from the treated plantlets.
\end{abstract}

Keywords: in vitro flowering; in vitro fruiting; plant growth regulator; plant retardant 


\section{Introduction}

Tomato (Lycopersicon esculentum Mill.) was originated in America [1] which then spread to all over the world, including Indonesia. Tomato is consumed as vegetable or fruit [2], that is why this plant is economically important. Beside, tomato has characteristics that make it suitable as model plant, such as its relatively compact genome (950 Mb), rich germ plasm, as well as a very efficient transformation protocol [3].

In vitro flowering and fruiting of tomato has some advantages, i.e. to overcome plants that have difficulties in producing seeds naturally, to rescue threatened plants [4]; to avoid the transmission of diseases in vegetative-propagated plants [5]; and to study the physiology and development of flowers in plants [6].

Some studies in in vitro flowering and fruiting have been done in tomato. Sheeja and Mandal (2003) [6] treated the callus of tomato var. Pant 11 explants by using $2 \mathrm{mg} . \mathrm{L}^{-1}$ BAP. They obtained the highest rate of flower bud formation by using that treatment. In line with that, Mamidala and Nanna (2009) [7] investigated the formation of in vitro flower and fruit of plantlets grown from the leaf explants of dwarf tomato cv. Micro-Msk. This experiment successfully produced in vitro flowers and fruits after 8 weeks incubation with the addition of 6-benzylaminopurine (BAP) and indole-3-acetic acid (IAA) and also Zeatin and IAA.

Experiments in plant tissue culture are always specific based on the species, variety or cultivar. This experiment aimed to establish a standard procedure for plant tissue culture experiment. While all this time, this experiment has never been done in tomato var. Tymoti. The variant has a great potencial to be developed because it has some superiorities among others, i.e. its endurance against higher temperature, its resistency to Gemini Virus and Blossom End Rot, and also its high yield [8].

\section{Materials and methods}

\subsection{Chemicals}

$\mathrm{NaOH}$ and $\mathrm{HCl}$ were used to set the $\mathrm{pH}$ of the culture media. Bayclin $®(\mathrm{NaOCl} 5.25 \%)$ was used to surface sterilize the plant materials. The plant growth regulators used were 6-benzylamino $\mathrm{Pu}$ rine (BAP), indole acetic acid (IAA), and gibberellin GA3. Plant retardants were also used in this experiment, i.e. paclobutrazol and ancymidol. In this experiment, $\mathrm{KH}_{2} \mathrm{PO}_{4}$ was also added to the particular treated medium. $\mathrm{KH}_{2} \mathrm{PO}_{4}$ is the source of phosphate for the plants. Phosphate is important during generative phase [9] to promote a high quantity and good quality of flowers and fruits.

\subsection{Plant materials}

Explants were obtained from tomato seeds var. Tymoti (East-West Seed Cap Panah Merah®). This kind of tomato can live in lowland, can tolerate hot climate, and has resistance to Gemini virus disease, wilt, and rotten fruit tip [8]. The seeds were washed gently under running tap water before the sterilization. For the germination, each of 15 culture bottles was filled with cotton and subsequently poured by $10 \mathrm{~mL}$ BAP solution in concentration of $1 \mathrm{mg} . \mathrm{L}^{-1}$. The $\mathrm{pH}$ was set at 5.6. These culture bottles were then autoclaved at $121^{\circ} \mathrm{C}$ and $1.5 \mathrm{~atm}$ for 20 minutes.

\subsection{Method development and validation}

\subsubsection{Surface sterilization}

The washed seeds were soaked in $2.6 \% \mathrm{NaOCl}$ solution for 5 minutes and $1.8 \% \mathrm{NaOCl}$ solution for 15 minutes, respectively. Seeds were washed three times with sterile distilled water, dried and cultured in the sterile culture bottles that contained cotton and BAP solution. There were 10 15 seeds in every culture bottle.

\subsubsection{Culture Media}

One liter Murashige \& Skoog (MS) media was made by dissolving 4.43 g powder of MS Basal Medium with vitamins (PhytoTechnology Labo- 
ratories) into a beaker glass contained $500 \mathrm{~mL}$ distilled water. As much as $30 \mathrm{~g}$ sucrose and 12 $\mathrm{g}$ agar were also added into it. After fixing the $\mathrm{pH}$ at 5.8, the distilled water was added again until reached $1000 \mathrm{~mL}$ volume. Before autoclaving, the solution was cooked with stirring until boiled.

There were five media variations tested in order to acquire the optimal sprouts condition. They are $1 / 2$ MS (G1), MS 0 (G2), 1 mg.L.-1 BAP solution (G3), MS basal medium with vitamins + $100 \mathrm{mg} . \mathrm{L}^{-1}$ myoinositol (G4), and MS basal medium with vitamin + 0.5 mg.L-1 BAP (G5). G1-G5 were codes for media variations, where G stands for germination. The criteria of optimal sprouts condition were the sprouts that underwent the fastest growth and had the strongest stem. The fastest growth measured from the day spent to form a complete sprout structure (it has root, hypocotyl, and cotyledon). The strongest stem observed from the diameter of the stem, that can be seen relatively among other treatments.

Five media were used to attain optimal condition for vegetative growth. They were MS 0 (V1), MS basal medium with vitamins $+100 \mathrm{mg} \cdot \mathrm{L}^{-1}$ myoinositol (V2), MS basal medium with vitamins +1 mg. L $^{-1}$ BAP (V3), MS basal medium with vitamins +1.5 mg. $L^{-1}$ BAP (V4), MS basal medium with vitamins $+2 \mathrm{mg} \cdot \mathrm{L}^{-1}$ BAP (V5). V1-V5 were the codes for the media used for growing of vegetative plantlets, while $\mathrm{V}$ stands for vegetative.

Sixteen combinations of plant growth regulator(s) and $\mathrm{KH}_{2} \mathrm{PO}_{4}$ were used in this experiment to promote in vitro flowers and fruits, as seen on Table 1. We also used paclobutrazol and ancymidol, each in a concentration of $1 \mathrm{mg} \cdot \mathrm{L}^{-1}$ to induce flowers and fruits in tomato plantlets.

\section{Result and discussion}

\subsection{Germination media}

Table 1. Plant growth regulators and $\mathrm{KH}_{2} \mathrm{PO}_{4}$ combination to induce in vitro flower and fruit

\begin{tabular}{|c|c|c|c|c|c|}
\hline \multirow[t]{2}{*}{ No. } & \multirow[t]{2}{*}{ Medium's Name } & \multicolumn{4}{|c|}{ Concentration in MS media (mg.L $\mathrm{L}^{-1}$ ) } \\
\hline & & IAA & GA3 & BAP & $\mathrm{KH}_{2} \mathrm{PO}_{4}$ \\
\hline 1 & MS 0 & 0 & 0 & 0 & 0 \\
\hline 2 & B1 & 0 & 0 & 1 & 0 \\
\hline 3 & $\mathrm{I} 0.5+\mathrm{GI} .5$ & 0.5 & 1.5 & 0 & 0 \\
\hline 4 & $\mathrm{I} 1+\mathrm{G} 1$ & 1 & 1 & 0 & 0 \\
\hline 5 & $\mathrm{I} 1.5+\mathrm{G} 0.5$ & 1.5 & 0.5 & 0 & 0 \\
\hline 6 & $\mathrm{I} 0.5+\mathrm{G} 1.5+\mathrm{K} 0.5$ & 0.5 & 1.5 & 0 & 0.5 \\
\hline 7 & $\mathrm{I} 1+\mathrm{G} 1+\mathrm{K} 0.5$ & 1 & 1 & 0 & 0.5 \\
\hline 8 & $\mathrm{I} 1.5+\mathrm{G} 0.5+\mathrm{K} 0.5$ & 1.5 & 0.5 & 0 & 0.5 \\
\hline 9 & $\mathrm{I} 0.5+\mathrm{G} 0.5+\mathrm{B} 1+\mathrm{K} 1$ & 0.5 & 0.5 & 1 & 1 \\
\hline 10 & $\mathrm{I} 0.5+\mathrm{G} 0.5+\mathrm{B} 1.5+\mathrm{K} 1$ & 0.5 & 0.5 & 1.5 & 1 \\
\hline 11 & $\mathrm{I} 0.5+\mathrm{G} 0.5+\mathrm{B} 2+\mathrm{K} 1$ & 0.5 & 0.5 & 2 & 1 \\
\hline 12 & $\mathrm{I} 0.5+\mathrm{B} 1$ & 0.5 & 0 & 1 & 0 \\
\hline 13 & $\mathrm{I} 0.5+\mathrm{B} 1.5$ & 0.5 & 0 & 1.5 & 0 \\
\hline 14 & $\mathrm{I} 0.5+\mathrm{B} 2$ & 0.5 & 0 & 2 & 0 \\
\hline 15 & $\mathrm{G} 0.5+\mathrm{B} 1$ & 0 & 0.5 & 1 & 0 \\
\hline 16 & $\mathrm{G} 0.5+\mathrm{B} 1.5$ & 0 & 0.5 & 1.5 & 0 \\
\hline 17 & $\mathrm{G} 0.5+\mathrm{B} 2$ & 0 & 0.5 & 2 & 0 \\
\hline
\end{tabular}


All of media used were successfully produced $80 \%$ healthy sprouts. For economic reason, $1 / 2 \mathrm{MS}$ (G1) and 1 mg.L.-1 BAP solution (G3) were chosen. These two media gave different result in term of stem rigidity (data is not shown). Seeds cultured on G1 medium looked fresher and more rigid than those cultured on G3. Yet G3 medium was more potential than G1 to produce flower and fruit in next step of experiment. G3 medium contained BAP which promotes axillary shoots growth so that the frequency of flower and fruit formation will be higher. Figure 1 shows the germination process from day 2 to day 7 .

\subsection{Vegetative growth media}

Among those five vegetative growth media, MS basal medium with vitamins $+1 \mathrm{mg} \cdot \mathrm{L}^{-1}$ BAP (V3), MS basal medium with vitamins + $1.5 \mathrm{mg} . \mathrm{L}^{-1}$ BAP (V4), and MS basal medium with vitamins + 2 mg.L.-1 BAP (V5) were better than the other two media (V1 and V2). This was probably because of the characteristic of BAP as the shoot formation inducer, so that the 14 days old sprouts that were moved in to these media had the better growth. Only, higher BAP concentration leads to higher formation of callus. This is why; it was decided to choose MS basal medium with vitamins +1 mg. $L^{-1}$ BAP (V3) for inducing in vitro fruit and flower. However, V4 or V5 media could also be an alternative if the propagator desired a faster growth. In the other hand, V1 and V2 were not recommended because it produced plantlets which had morphological and physiological abnormalities that generally called hyperhydricity. Hyperhydricity is an abnormality observed in in vitro plant because of the excessive uptake of water and the low lignifications in the tissue [10].

\subsection{Flower and fruit induction using plant growth regulator and $\mathrm{KH}_{2} \mathrm{PO}_{4}$}

Among sixteen treatments, there is only one treatment that successfully produced flower and fruit that is MS Basal Medium with vitamins
$+1 \mathrm{mg} \cdot \mathrm{L}^{-1}$ BAP (B1). There were two out of ten plantlets produced flowers, and only one plantlet produced a fruit. The development of flower bud to ripe fruit took 6 months and 6 days after the seeds germination. Table 2 and Figure 2 present the stages of flower development into a fruit.

The addition of phosphate $\left(\mathrm{KH}_{2} \mathrm{PO}_{4}\right)$ was objected to accelerate flower bud formation and fruit ripening. This is in accordance with the experiment conducted by Wiryanta (2004) [11], proposed that phosphate had a role in root and flower growth, as well as in fruit ripening. The deficiency of phosphate gave rise to disturbance in root growth and generative stage. However, in this experiment, the augmentation of phosphate caused roots grow more rapidly in comparison with the other media. Unfortunately, flower was not produced in this treatment. Murthy et al. [12] explained that there were many factors involved in in vitro flowering mechanism, i.e. light, carbohydrates, growth regulators, $\mathrm{pH}$, temperature, photoperiod, and so on.

\subsection{Flower and fruit induction using plant retardants}

There were two kinds of plant retardants that had been used, ancymidol and paclobutrazol, each in a concentration of $1 \mathrm{mg} . \mathrm{L}^{-1}$. Table 3 represents the effect of plant retardants on tomato plantlets.

Based on Table 3, we know that plant retardants give stunting effect to the plantlets. The average height of plantlets is $62 \%$ and $29 \%$ lower than control, on paclobutrazol and ancymidol respectively. This result is in line with Te-chato et al. (2009) [4] that the application of pacloburazol on Dendrobium orchid lead to the shorter internode. The average number of nodes is also lower on two treatments in comparison to control.

Te-chato et al. (2009) [4] reported that 0.05 mg. $\mathrm{L}^{-1}$ paclobutrazol can induce floral bud by $29 \%$ in in vitro Dendrobium orchid. Sakhidin et al. (2011) [13] also successfully increased the number of durian flower and fruit after the plants 

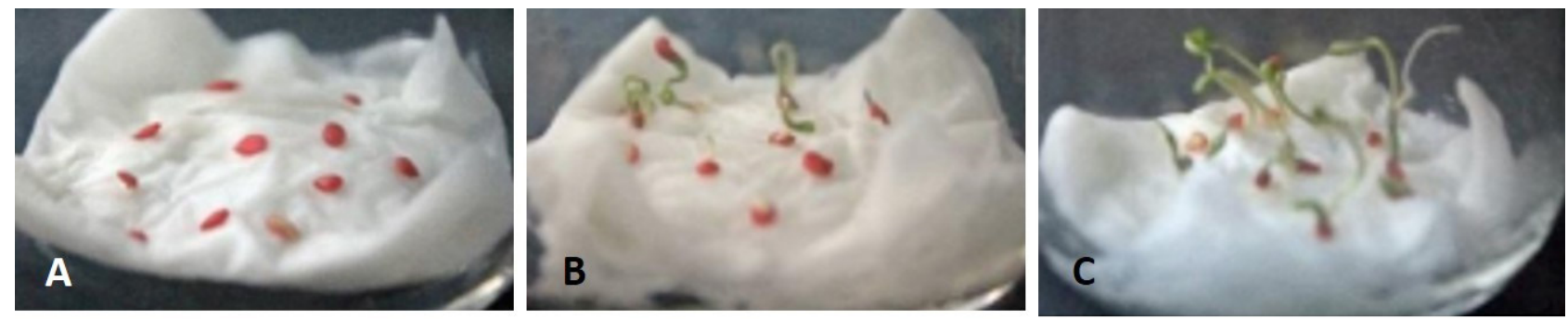

Figure 1. Seeds germination in 1 mg.L-1 BAP solution. A. 2 days; B. 5 days; C. 7 days.
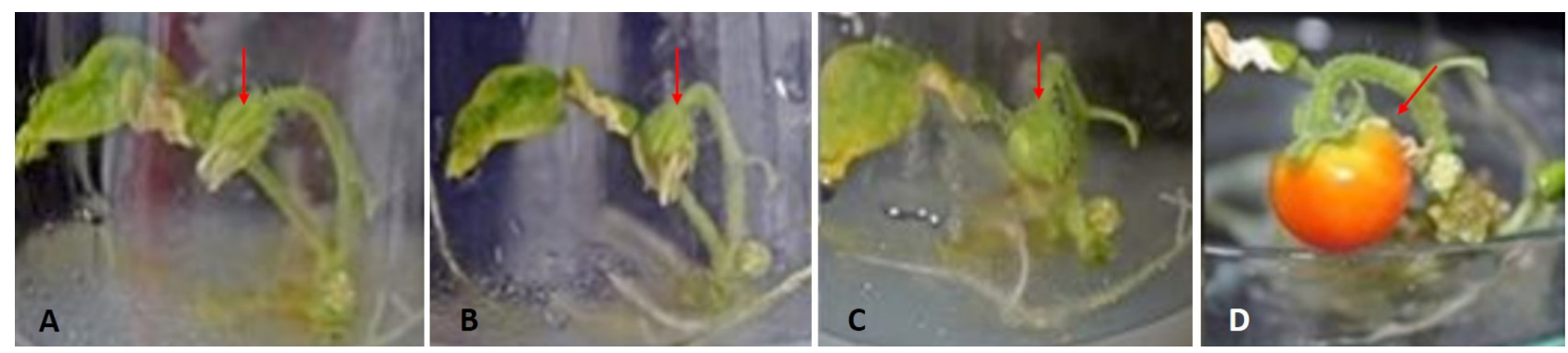

Figure 2. In vitro flower and fruit development on B1 (MS medium +1 mg.L $\mathrm{L}^{-1} \mathrm{BAP}$ ). A. flowers wilt at day 77; B. fruit set at day 79; C. fruit grows bigger at day 89; D. fruit is fully ripe at day 127 . Red arrow indicates flower or fruit.

Table 2. The stages of flower development in B1 (MS medium +1 mg. $\mathrm{L}^{-1} \mathrm{BAP}$ )

\begin{tabular}{lll}
\hline No. & Stage & Time Needed (Days) \\
\hline 1 & Flower buds formation & 23 \\
2 & Flower buds grow bigger & 2 \\
3 & Flower buds bloom & 19 \\
4 & Flowers wilt & 33 \\
5 & Fruit formation & 2 \\
6 & Fruit grows bigger & 6 \\
7 & Fruit is fully ripe & 38 \\
\hline
\end{tabular}

Table 3. Effects of plant retardants on tomato plantlets

\begin{tabular}{lllll}
\hline No. & Stage & Time Needed (Days) & Stage & Time Needed (Days) \\
\hline 1 & Control (MS0) & 3.4 & 4 & 0 \\
2 & Ancymidol $\left(1 \mathrm{mg} . \mathrm{L}^{-1}\right)$ & 2.4 & 3 & 0 \\
3 & Paclobutrazol $\left(1 \mathrm{mg} \cdot \mathrm{L}^{-1}\right)$ & 1.3 & 2 & 0 \\
\hline
\end{tabular}

were treated by $4 \mathrm{~g}$ paclobutrazol. In addition, there was a report explained that paclobutrazol could increase fruit formation and promotes early fruit in tomato plants [14], yet there was no report about the application of paclobutrazol in in vitro tomato. However, no flower buds are formed in this experiment. We assumed the concentration of paclobutrazol might be too high. Techato et al. (2009) [4] explained that the adding of $0.1 \mathrm{mg} . \mathrm{L}^{-1}$ paclobutrazol in in vitro Dendrobium orchid gave the lowest result on flower formation.

The use of ancymidol in inducing flowering 
and fruiting in plants is rarely reported recently. In 2016, Abdel-Moniem [15] reported that the use of ancymidol in combination with daminozide and ethephon successfully increase the number of ray flowers/head in Helianthus annuus. Unfortunately, there is no report of ancymidol effect on tomato flowering and fruiting.

\section{Conclusion}

In this experiment, in vitro flowers and fruits are achieved by using MS basal medium + vitamins incorporated with $1 \mathrm{mg} . \mathrm{L}^{-1}$ BAP. Nevertheless, the frequency of flowers and fruit formation is very small. So, there is a need to develop a new method to produce in vitro flower and fruit in a high yield. Also, there must be a way to shorten the reproduction cycle of in vitro tomato, so that the in vitro flowers and fruits can be obtained in a short time.

\section{Acknowledgement}

We thank to Lembaga Penelitian dan Pengabdian kepada Masyarakat (LPPM) Universitas Surabaya for fully funding this experiment. Also, we would like to thank to our laboratory assistants for the intensive helps to support our works.

\section{References}

1. van Steenis CGGJ, Bloembergen S, Eyme PJ. Flora. Jakarta: PT. Balai Pustaka; 2013.

2. Jaya B.Produksi Benih Calon Varietas Tomat Untuk Persiapan Pelepasan Varietas 1804.17.C.3.3. Lembang: Balai Penelitian Tanaman Sayuran; 2011.

3. Carvalho RF, Campos ML, Pino LE, Crestana SL, Zsögön A, Lima JE, Benedito VA, Peres LE. Convergence of developmental mutants into a single tomato model system:'Micro-Tom'as an effective toolkit for plant development research. Plant Methods. 2011;7(1):18.

4. Te-Chato S, Nujeen P, Muangsorn S. Paclobutrazol enhance budbreak and flowering of Friederick's Dendrobium orchid in vitro.Journal of Agricultural Technology. 2009;5(1):157-65.

5. Bermawie, et all. Induksi pembungaan dan studi fenologi bunga pada tanaman jahe putih besar (Zingiber officinale rosc.) Var cimanggu 1. Laporan Teknis Penelitian Tahun Anggaran 2010. Jakarta: Balai Penelitian Tanaman Obat dan Aromatik; 2010:281-97.

6. Sheeja TE, Mandal AB. In vitro flowering and fruiting in tomato (Lycopersicon esculentum Mill.). Asia Pacific Journal of Molecular Biology \& Biotechnology. 2003;11(1):37-42.

7. Praveen M, Nanna RS. Efficient in vitro plant regeneration, flowering and fruiting of dwarf Tomato cv. Micro-Msk. Plant Omics. 2009;2(3):98102.

8. Panah Merah. 2017. Tymoti F1. http://www. panahmerah.id/product/tymoti-f1.

9. NPK Industries. __. Bigger Flowers and Fruits with Phosphorus. http://npk-industries.com/ plant_nutrition_phosphorus.html

10. Bhatia S, Sharma K, Dahiya R, Bera T. Modern applications of plant biotechnology in pharmaceutical sciences. London: Academic Press; 2015: 393-404. https://www. sciencedirect.com/science/article/pii / B9780128022214000133. Accessed on 6th September, 2018.

11. Wiryanta WTB. Bertanam Tomat. Jakarta: Agromedia Pustaka; 2004.

12. Murthy KS, Kondamudi R, Chalapathi Rao PV, Pullaiah T. In vitro flowering-A review. J Agric Technol. 2012;8:1517-36.

13. Suparto SR. Kandungan giberelin, kinetin, dan asam absisat pada tanaman durian yang diberi paklobutrazol dan etepon. Jurnal Hortikultura Indonesia. 2012;2(1):21-6.

14. Berova M, Zlatev Z. Physiological response and yield of paclobutrazol treated tomato plants 
(Lycopersicon esculentum Mill.). Plant Growth Regulation. 2000;30(2):117-23.

15. Abdel-Moniem AM. Effect of some growth retardants on growth and flowering of Helianthus annuus L. cv. Sunrich orange summer 981v plants b- application of ancymidol, daminozide and ethephon in combinations. Scientific J. Flowers \& Ornamental Plants. 2016;3(2):119-34. 